\title{
Study on occurrence of the IVS8-5T allele of the CFTR gene in Ukrainian males with spermatogenesis failure
}

\author{
O. A. Fesai, S. A. Kravchenko, V. M. Zinchenko'1, L. A. Livshits \\ Institute of Molecular Biology and Genetics of National Academy of Sciences of Ukraine \\ 150, Akademika Zabolotnogo str., Kyiv, Ukraine, 03680 \\ ${ }^{1}$ Clinic «ISIDA-IVF»65, Ivana Lepse boulevard, Kyiv, Ukraine, 03126 \\ olga_fesay@ukr.net
}

\begin{abstract}
Aim. To study the IVS8-5T allele of the CFTR gene and it is involvement in spermatogenesis failure in men with azoospermia and oligozoospermia. Methods. The IVS8-nT polymorphism was analyzed by PCR followed by «A.L.F.-express» fragment analysis in the infertile men group, consisting of 113 azoospermic and 217 oligozoospermic patients, and the control group of 150 fertile men with proven paternity. Results. The frequency of the IVS8-5T allele among infertile males was higher than in controls. A statistically significant difference $(P<0.05)$ was observed in the frequencies of the IVS8-5T allele in azoospermia patients $(5.3 \%)$ when compared with the control group $(2.0 \%)$. Conclusions. The IVS8-5T allele of the CFTR gene contributes to spermatogenesis failure and/or sperm maturation.
\end{abstract}

Keywords: male infertility, spermatogenesis failure, IVS8-nT polymorphism.

Introduction. Many genes are likely to be involved in the complex process of reproduction [1]. The main genetic causes of male infertility are microdeletions in the Y chromosome ( $A Z F$ region) connected with oligozoospermia or azoospermia. Infertility, or at least subfertility, in males with Cystic Fibrosis (CF) was first suspected in the 1960s. Abnormalities in semen parameters have also been identified in males with $\mathrm{CF}$ and CBAVD (congenital bilateral absence of the vas deferens) [2]. It were suggested that the frequency of CFTR (cystic fibrosis transmembrane conductance regulator) gene mutations in infertile males was significantly higher than the expected CF carrier frequency in the general population [3].

The CFTR gene contains 27 exons encompassing $\sim 180 \mathrm{~kb}$ of DNA on chromosome band 7q31.2. The CFTR gene encodes a transmembrane protein that

(C) Institute of Molecular Biology and Genetics NAS of Ukraine, 2010 forms a cAMP-regulated chloride channel. It is expressed in epithelial cells of exocrine tissues, such as the lungs, pancreas, epididymal glands, vas deferens and seminal vesicles [4]. Three length variations of a polythymidine tract within the splice acceptor site in the introne 8 of the CFTR gene (GenBank accession no. M55106) have been associated with variable efficiency of the exon 9 splicing [5].

The most frequent CFTR mutation conferring a mild phenotype found in CBAVD patients is the IVS8-5T allele [6]. IVS8-5T is one of the alleles found at the polymorphic nT locus in the intron 8 of the CFTR gene. A stretch of 5, 7, or 9 thymidine residues is found at this locus. Less efficient splicing occurs when a lower number of thymidines are present, resulting in the CFTR transcripts that lack the exon 9 sequences [7].

Alternatively, the spliced CFTR transcripts lacking the exon 9 sequences are found in any individual, but the extent varies depending on the alleles present at the 
nT locus. In individuals homozygous for the IVS8-5T allele up to $90 \%$ of the CFTR transcripts lack the exon 9 [7]. It has been shown that the $C F T R$ transcripts lacking the exon 9 sequences result in the CFTR proteins that do not mature $[8,9]$. The IVS8-5T variant produces a lower level of the normal CFTR mRNA transcripts than the 7T and 9T alleles and is associated with disseminated bronchiectasis, CBAVD and epididymal obstruction [7]. In addition to the classic CFTR mutations, up to $40 \%$ of CBAVD patients show the IVS8$5 \mathrm{~T}$ allele, that is five thymidines tract within the intron $8[6,10,11]$, which results in a reduction of the CFTR gene splicing efficacy [7].

The aim of this study was to establish the association between the IVS8-5T allele and defects of spermatogenesis. For this we analyzed the IVS8-nT CFTR gene polymorphism in infertile men.

Materials and methods. The analysis of the IVS8-nT polymorphism of the CFTR gene was performed in 330 infertile men from Ukraine (113 with azoospermia - no sperm found in the ejaculate even after centrifugation and 217 with oligozoospermia sperm count $<20 \mathrm{million} / \mathrm{ml}$ ). All patients from «ISIDA-IVF», «NADIJA» clinics and Institute of Genetics and Reproduction were involved in ICSI (intracytoplasmic sperm injection) program. The control group consisted of 150 fertile men of proven fertility (have fathered at least one child each, paternity being proven). Blood samples $(5 \mathrm{ml})$ from both infertile and fertile men were collected after their informed written consent.

DNA was extracted out from the peripheral blood leukocytes by standard phenol-chloroform extraction methods using proteinase K («Fermentas», Lithuania) [12]. For DNA extraction and purification we used eppendorf centrifuge 5415C («Eppendorf», Germany).

The CFTR mutation analysis was performed for 6 mutations: delF508, CFTRdele2,3 (21kb), N1303K, $\mathrm{R} 117 \mathrm{H}, 1677$ delTA and $621+1 \mathrm{G}-\mathrm{T}$ as previously described [13].

For the IVS8-nT polymorphism the PCR amplification was performed with specific oligonucleotide primers, as described by Chillon M. et al. [6]. The PCR reaction was performed in a final volume of $25 \mu \mathrm{l}$ containing $1 \times$ PCR buffer, $1.5 \mathrm{mM} \mathrm{MgCl}_{2}, 200 \mathrm{MM}$ of each dNTP, $1 \mu \mathrm{M}$ of each primer, 0.2 units of Taq-DNA polymerase («Fermentas», Lithuania) and $200 \mathrm{ng}$ of the DNA template.

The cycling conditions for the IVS8-nT polymorphism were as follows: initial denaturation at $96{ }^{\circ} \mathrm{C}$ for 4 min up to 5 cycles, consisting of denaturation at $96^{\circ} \mathrm{C}$ for $40 \mathrm{~s}$, annealing at $66^{\circ} \mathrm{C}$ for $40 \mathrm{~s}$, extension at $72{ }^{\circ} \mathrm{C}$ for $1 \mathrm{~min} 50 \mathrm{~s}$, up to 23 cycles, consisting of denaturation at $95{ }^{\circ} \mathrm{C}$ for $30 \mathrm{~s}$, annealing at $64{ }^{\circ} \mathrm{C}$ for $40 \mathrm{~s}$, extension at $70{ }^{\circ} \mathrm{C}$ for $1 \mathrm{~min} 30 \mathrm{~s}$, and final elongation step at $72{ }^{\circ} \mathrm{C}$ for $3 \mathrm{~min}$. For these experiments Applied Biosystems GeneAmp PCR system 2720 Termal Cycler («Applied Biosystems», USA) was used. Electrophoresis of the PCR products was performed in $1.8 \%$ agarose gel.

For fragment analysis of the IVS8-nT polymorphism in an automated laser fluorometer «A.L.F.-express» («Amersham Pharmacia Biotech», Sweden) the Cy5-labeled PCR products were used. The PCR fragment analysis was performed using the Fragment Manager Computer program (Fragment Manager Software V2.1, «Amersham Pharmacia Biotech») (Fig. 1).

The statistical analysis was performed using Genepop software [14]. Differences were considered significant at $\mathrm{P}<0.05$ value of Fisher exact test.

Results and discussion. Genotypes and allele frequencies of the IVS-nT polymorphism analyzed among 330 infertile men are presented in Table.

In the patients' group of we have found 21 individuals with the IVS8-5T allele in compound heterozygosity with the IVS8-7T and IVS8-9T alleles. Two patients were identified as homozygous for the IVS8-5T allele. In the control group we have found 4 individuals with the IVS8-5T allele in compound heterozygosity with the IVS8-7T and IVS8-9T alleles. One patient was identified as homozygous for the IVS8-5T allele.

It is important to note that genotypes which included the IVS8-5T allele were significantly prevalent $(\mathrm{P}<0.01)$ in patients with azoospermia $(9.7 \%)$ compared to the control group (3.3\%) $(\mathrm{OR}=3.128,95 \%$ CI 1.055-9.275). The frequency of the IVS8-5T allele among infertile males was $3.8 \%, 1.9$-fold higher than in the controls $(2.0 \%)$. A statistically significant difference $(\mathrm{P}<0.05)$ was observed in the frequency of the IVS8-5T allele in azoospermia patients $(5.3 \%)$ when compared with the control group $(2.0 \%)(\mathrm{OR}=2.748$, $95 \%$ CI 1.015-7.437). 
Genotype and allele distribution among the infertile and control groups

\begin{tabular}{|c|c|c|c|c|}
\hline & $\begin{array}{l}\text { Azoospermia } \\
\text { group, } n(\%)\end{array}$ & $\begin{array}{l}\text { Oligozoospermia } \\
\text { group } n(\%)\end{array}$ & $\begin{array}{c}\text { Infertile } \\
\text { group } n(\%)\end{array}$ & $\begin{array}{c}\text { Control } \\
\text { group } n(\%)\end{array}$ \\
\hline \multicolumn{5}{|c|}{ Genotype } \\
\hline $5 \mathrm{~T} / 5 \mathrm{~T}$ & $1(0.9)$ & $1(0.5)$ & $2(0.6)$ & $1(0.7)$ \\
\hline $5 \mathrm{~T} / 7 \mathrm{~T}$ & $5(4.4)$ & $10(4.6)$ & $15(4.6)$ & $3(2.0)$ \\
\hline $5 \mathrm{~T} / 9 \mathrm{~T}$ & $5(4.4)$ & $1(0.5)$ & $6(1.8)$ & $1(0.7)$ \\
\hline $7 \mathrm{~T} / 7 \mathrm{~T}$ & $81(71.7)$ & $161(74.2)$ & $\begin{array}{c}242 \\
(73.3)\end{array}$ & $125(83.3)$ \\
\hline $7 \mathrm{~T} / 9 \mathrm{~T}$ & $16(14.2)$ & $39(17.9)$ & $55(16.7)$ & $12(8.0)$ \\
\hline $9 \mathrm{~T} / 9 \mathrm{~T}$ & $5(4.4)$ & $5(2.3)$ & $10(3.0)$ & $8(5.3)$ \\
\hline \multicolumn{5}{|c|}{ Allele } \\
\hline $5 \mathrm{~T}$ & $12(5.3)$ & $13(2.9)$ & $25(3.8)$ & $6(2.0)$ \\
\hline $7 \mathrm{~T}$ & $\begin{array}{c}183 \\
(80.9)\end{array}$ & $371(85.5)$ & $\begin{array}{c}554 \\
(83.9)\end{array}$ & $265(88.3)$ \\
\hline 9T & $31(13.7)$ & $50(11.5)$ & $81(12.3)$ & $29(9.7)$ \\
\hline
\end{tabular}

Azoospermia group, $n=113$; oligozoospermia group $(n=217)$; infertile group $(n=330)$; control group $(n=150)$

This increased IVS8-5T allele frequency in men with azoospermia suggests that the CFTR protein could be involved in the process of spermatogenesis or sperm maturation. It could also play a crucial role in the development of the epididymis glands and the vas deferens [15].

The IVS8-5T allele is known to give rise to an aberrantly spliced mRNA that mostly lacks the exon 9 . Such anomalous mRNA is translated into the abnormal CFTR protein which cannot function as a $\mathrm{Cl}^{-}$channel. Therefore, men with the IVS8-5T variant in the noncoding region of the gene would produce low level of normal CFTR protein in the epididymis, especially in homozygous mutant individuals [16]. Chillon showed that the IVS8-5T allele was significantly more frequent in the chromosomes of patients with CBAVD than in the European general population [6].

In our study the proportion of the men with azoospermia (part of which may have undiagnosed CBAVD) who had the IVS8-5T allele (9.7 \%) was higher than that in the European general population (5.2\%), and in our control group (3.3\%). Approximately the same percentage of the IVS8-5T allele carriers was found in the men with CBAVD from different countries [17].

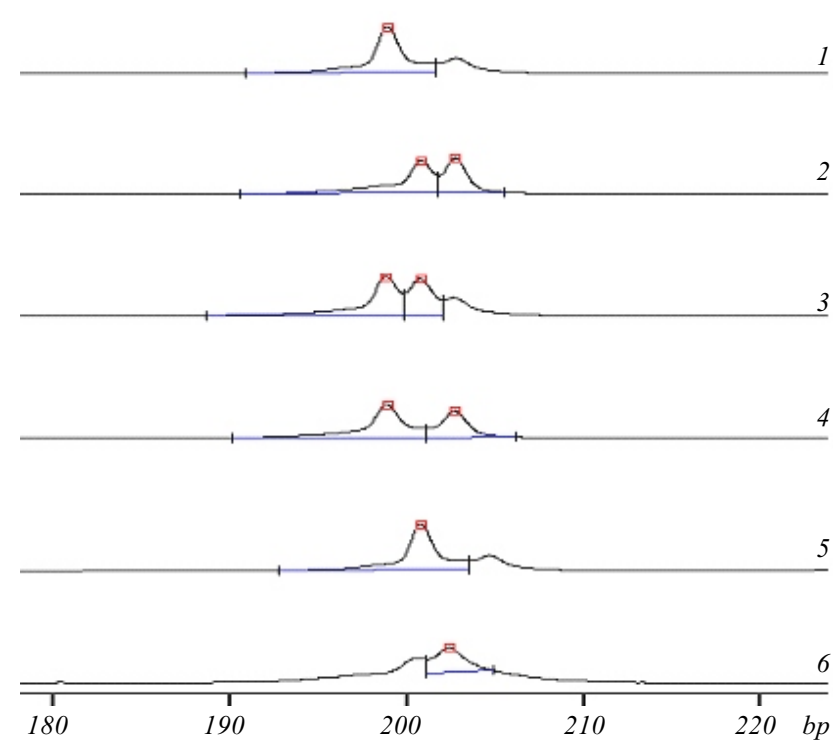

Fig. 1. An example of analysis of the IVS8-nT polymorphism with the use of «A.L.F.-express». Genotypes: $1-5 \mathrm{~T} / 5 \mathrm{~T} ; 2-7 \mathrm{~T} / 9 \mathrm{~T} ; 3-$ $5 \mathrm{~T} / 7 \mathrm{~T} ; 4-5 \mathrm{~T} / 9 \mathrm{~T} ; 5-7 \mathrm{~T} / 7 \mathrm{~T} ; 6-9 \mathrm{~T} / 9 \mathrm{~T}$

Also, it has been shown that mutations of the CFTR gene expressed in the proximal epididymis can lead to agenesis of the distal epididymis and vas deferens [18].

The results of CFTR gene mutation analysis performed in the group of infertile males $(n=330)$ show that the delF508 mutation was found in 16 patients (4.8\%), CFTRdele2,3 $(21 \mathrm{~kb})$ in 2 patients $(0.6 \%)$ and $\mathrm{R} 117 \mathrm{H}$ in 1 patient $(0.3 \%)$. It is important to note that the $\mathrm{R} 117 \mathrm{H}$ mutation was not found either in the general population or in the group of $\mathrm{CF}$ patients from Ukraine [13]. Therefore, the frequency of CFTR gene mutation carriers in the azoospermia group $(n=113)$ was $10.6 \%$. The frequency of CFTR gene mutation carriers in the infertile men $(n=330)$ was $5.8 \%$. In our previous study we showed that the total frequency of the CFTR gene mutations in Ukrainian population $(n=621)$ was $0.97 \%$ [13]. It is significantly lower $(\mathrm{P}<0.01)$ than in the group of men with spermatogenesis failure $(n=$ $=330$ ).

It has been shown that the compound heterozygotes for the IVS8-5T allele and other CFTR mutation display a variable phenotype, ranging from normal to male infertility or nonclassic CF [17]. For example, when the IVS8-5T allele is found in the compound heterozygosity with a severe $C F T R$ mutation, or even the IVS8-5T allele, the pathology such as CBAVD was observed. The IVS8-5T allele, in combination with a 
single mutation in the other chromosome, is common in CBAVD and accounts for the observed Wolffian duct abnormalities [19].

However, not all males who are compound heterozygous for the severe CFTR mutation and IVS8-5T allele develop CBAVD. In our study four patients $(1.2 \%)$ with azoospermia and oligozoospermia have the CFTR mutation in combination with the $5 \mathrm{~T} / 7 \mathrm{~T}$ and 5T/9T genotypes. Therefore, the results of this study confirm that the IVS8-5T allele can be classified as a disease mutation with partial penetrance [20] and a high risk genetic variant for male infertility. This suggesting is quite possible since the level of the CFTR gene expression is very high in the cells from different departments of male genital.

Conclusions. The prevalence of the IVS8-5T allele $(\mathrm{P}<0.05)$ and the CFTR mutation in males with azoospermia, suggests that the CFTR protein may play a crucial role in the spermatogenesis and/or sperm maturation, independently of its functioning in the development of epithelial ducts such as the vas deferens.

Acknowledgements. We thank the staff at the clinic «ISIDA-IVF», clinic «NADIJA» and Institute of Genetics and Reproduction for their kind assistance in collecting the blood samples.

\section{О. А. Фесай, С. А. Кравченко, В. М. Зінченко, Л. А. Лівшицฺь}

Дослідження частоти алеля IVS8-5T гена CFTR в українських чоловіків із порушенням сперматогенезу

Резюме

Mema. Дослідити алель IVS8-5T гена CFTR і його залучення до порушенням сперматогенезу у чоловіків із азооспермією та олігозооспермією. Методи. IVS8-nT-поліморфізм аналізували у групі безплідних чоловіків, яку склали 113 пацієнтів із азооспермією та 217 паиієнтів із олігозооспермією, та в контрольній групі, до якої увійшли 150 фертильних чоловіків із підтвердженим батьківством, 3 використанням ПЛР та фрагментного аналізу «A..L.F.-ехpress». Результати. Частота появи алеля IVS8-5T серед безплідних чоловіків була вищою, ніж у контролі. Статистично достовірну різницю $(P<0,05)$ визначено за частотами IVS8-5T-алеля у пацієнтів із азооспермією (5,3\%) порівняно з контрольною групою (2,0\%). Висновки. Алель IVS8-5T гена CFTR сприяє порушенню сперматогенезу і/або дозріванню сперматозоїдів.

Ключові слова: чоловіче безпліддя, порушення сперматогенезу, IVS8-nT-поліморфізм.
О. А. Фесай, С. А. Кравченко, В. М. Зинченко, Л. А. Лившии

Исследование частоты аллеля IVS8-5T гена CFTR у украинских мужчин с нарушением сперматогенеза

Резюме

Цель. Изучение аллеля IVS8-5T гена CFTR и его вовлечение в нарушение сперматогенеза у мужчин с азооспермией и олигозооспермией. Методы. IVS8-nT-полиморфизм исследовали в группе бесплодных мужчин, которую составили 113 пациентов с азооспермией и 217 пациентов с олигозооспермией, и контрольной группе, куда вошли 150 фертильных мужчин с подтвержденным отиовством, с использованием ПЦР и фрагментного анализа с «A.L.F.-express». Результаты. Частота появления IVS8-5T-аллеля среди бесплодных мужчин была выше, чем в контроле. Статистически достоверная разница $(P<0,05)$ определена по частоте IVS8-5T-аллеля у пациентов $c$ азооспермией (5,3\%) по сравнению с контрольной группой (2,0\%). Выводы. IVS8-5T-аллель гена CFTR способствует нарушению сперматогенеза и/или дозреванию сперматозоидов.

Ключевые слова: мужское бесплодие, нарушение сперматогенеза, IVS8-nT-полиморфизм.

\section{REFERENCES}

1. Mak V., Zielenski J., Tsui L. C., Durie P., Zini A., Martin S., Longley T. B., Jarvi K. A. Proportion of cystic fibrosis gene mutations not detected by routine testing in men with obstructive azoospermia // JAMA.-1999.-281, N 23.-P. 2217-2224.

2. Dohle G. R., Halley D. J. J., Van Hemel J. O., van den Ouwel A. M. W., Pieters M. H. E. C., Weber R. F. A., Govaerts L. C. $P$. Genetic risk factors in infertile men with severe oligozoospermia and azoospermia // Hum. Reprod.-2002.-17, N 1.P. 13-16.

3. Van der Ven K., Messer L., Van der Ven H., Jeyendran R. S., Ober $C$. Cystic fibrosis mutation screening in healthy men with reduced sperm quality // Hum. Reprod.-1996.-11, N 3.P. 513-517.

4. Radpour R., Salahshourifar I., Gourabi H., Gilani M., Dizaj $A$. CFTR mutations in congenital absence of vas deferens // Iran J. Fertil. and Steril.-2007.-1, N 1.-P. 1-10.

5. Mak V., Jarvi K. A., Zielinski J., Durie P., Tsui L. C. Higher proportion of intact exon 9 CFTR mRNA nasal epithelium compared with vas deferens // Hum. Mol. Genet.-1997.-6, N 12.-P. 2099-2107.

6. Chillon M., Casals T., Mercier B., Bassas L., Lissens W., Silber S., Romey M. C., Ruiz-Romero J., Verlingue C., Claustres M., Nunes V., Ferec C., Estivill X. Mutations in the cystic fibrosis gene in patients with congenital absence of the vas deferens // N. Engl. J. Med.-1995.-332, N 22.-P. 1475-1480.

7. Chu C. S., Trapnell B. C., Curristin S., Cutting G. R., Crystal $R$. G. Genetic basis of variable exon 9 skipping in cystic fibrosis transmembrane conductance regulator mRNA // Nat. Genet.-1993.-3, N 2.-P. 151-156.

8. Delaney S. J., Rich D. P., Thomson S. A., Hargrave M. R., Lovelock P. K., Welsh M. J., Wainwright B. J. Cystic fibrosis transmembrane conductance regulator splice variants are not conserved and fail to produce chloride channels // Nat. Genet.-1993.-4, N 4.-P. 426-431.

9. Strong T. V., Wilkinson D. J., Mansoura M. K., Devor D. C., Henze K., Yang Y., Wilson J. M., Cohn J. A., Dawson D. C., 
Frizzell R. A., Collins F. S. Expression of an abundant alternatively spliced from of the cystic fibrosis transmembrane conductance regulator $(C F T R)$ gene is not associated with a cAMP-activated chloride conductance // Hum. Mol. Genet.1993.-2, N 3.-P. 225-230.

10. Dork T., Dworniczak B., Aulehla-Scholz C., Wieczorek D., Bohm I., Mayerova A., Seydewitz H. H., Nieschlag E., Meschede D., Horst J., Pander H.-J., Sperling H., Ratjen F., Passarge E., Schmidtke J., Stuhrmann M. Distinct spectrum of CFTR gene mutations in congenital absence of vas deferens // Hum. Genet.-1997.-100, N 3-4.-P. 365-377.

11. Jarvi K., McCallum S., Zielenski J., Durie P., Tullis E., Wilchanski M., Margolis M., Asch M., Ginzburg B., Martin S., Buckspan M. B., Tsui L. C. Heterogeneity of reproductive tract abnormalities in men with absence of the vas deferens: role of cystic fibrosis transmembrane conductance regulator gene mutations // Fertil. Steril.-1998.-70, N 4.-P. 724-728.

12. Maniatis T., Fritsch E. F., SambrookJ. Molecular cloning: A laboratory manual.-New York: Cold Spring Harbor Lab. publ., 1982.-545 p.

13. Fesai O. A., Pampukha V. M., Solovyov O. O., Livshits L. A. Analysis of defects in the AZF gene of the Y-chromosome and the CFTR gene involved in male infertility // Biopolym. cell.-2008.-24, N 3.-P. 231-237.

14. Raymond M., Rousset F. GENEPOP (version 1.2): population genetics software for exact tests and ecumenicism // J. Hered.-1995.-86, N 3.-P. 248-249.

15. Trezise A., Linder C., Grieger D., Thompson E., Meunier H., Griswold M., Buchwald M. CFTR expression is regulated during both the cycle of the seminiferous epithelium and the oc- strous cycle of rodents // Nat. Genet.-1993.-3, N 2.-P. 157164.

16. Wong P. Y. D. CFTR gene and male fertility // Mol. Hum. Reprod.-1998.-4, N 2.-P. 107-110.

17. Groman J. D., Hefferon T. W., Casals T., Bassas L., Estivill X., Georges M. D., Guittard C., Koudova M., Fallin M. D., Nemeth K., Fekete G., Kadasi L., Friedman K., Schwarz M., Bombieri C., Pignatti P. F., Kanavakis E., Tzetis M., Schwartz M., Novelli G., D’Apice M. R., SobczynskaTomaszewska A., Bal J., Stuhrmann M., Macek M. Jr., Claustres M., Cutting G. R. Variation in a repeat sequence determines whether a common variant of the cystic fibrosis transmembrane conductance regulator gene is pathogenic or benign // Am. J. Hum. Genet.-2004.-74, N 1.-P. 176-179.

18. Turner T. T. De graaf's thread: the human epididymis // J. Androl.-2008.-29, N 3.-P. 237-250.

19. Lyon A., Bilton D. Fertility issues in cystic fibrosis // Paediatr. Respir. Rev.-2002.-3, N 3.-P. 236-240.

20. Cuppens H., Lin W., Jaspers M., Costes B., Teng H., Vankeerberghen A., Jorissen M., Droogmans G., Reynaert I., Goossens M., Nilius B., Cassiman J. J. Polyvariant mutant cystic fibrosis transmembrane conductance regulator genes - the polymorphic $(\mathrm{TG})_{\mathrm{n}}$ locus explains the partial penetrance of the $5 \mathrm{~T}$ polymorphism as a disease mutation // J. Clin. Invest.1998.-101, N 2.-P. 487-496.

UDC $575.11+577.21+616.697$ Recieved 01.04.10 